\title{
Drivers and Consequences of Recurrent Conflicts between Farmers and Pastoralists in Kilosa and Mvomero Districts, Tanzania
}

\author{
Emmanuel M. Falanta ${ }^{1}$ \& Kenneth M. K. Bengesi ${ }^{2}$ \\ ${ }^{1}$ Departmentof Development Studies, College of Social Sciences and Humanities, Sokoine University of \\ Agriculture, Morogoro, Tanzania \\ ${ }^{2}$ Department of Policy Planning and Management, College of Social Sciences and Humanities, Sokoine \\ University of Agriculture, Morogoro, Tanzania \\ Correspondence: Emmanuel M. Falanta, Department of Development Studies, P.O. Box 3024 Chuo Kikuu, \\ Morogoro, Tanzania. Tel: 255-754-821-634.E-mail: emmfal@gmail.com
}

Received: October 25, 2017

Accepted: June 12, $2018 \quad$ Online Published: July 232018

doi:10.5539/jsd.v11n4p13

URL: https://doi.org/10.5539/jsd.v11n4p13

\begin{abstract}
Recurrent conflicts between farmers and pastoralists have brought significant impacts on both groups. In response to this situation, the government and other actors have taken several measures to mitigate such conflicts with little success. This paper examined drivers and consequences of recurrent conflicts between farmers and pastoralists in Kilosa and Mvomero districts. Covering a sample size of 203 respondents, data was collected using interview, documentary review, and focus group discussions. Collected data was analyzed using both qualitative and quantitative analysis. The findings revealed that weak governance structures associated with unethical behavior, regulatory deficiencies, socio-economic and environmental factors are responsible for the recurrence of conflicts between farmers and pastoralists. Consequently, the recurrent conflicts have resulted into major socio-economic impact that includes loss of lives and properties to both farmers and pastoralists. Drawing from conflict and conflict resolution theories, which advocates use of coercive power and participatory approaches to restore peace, respectively; this paper conclude that no single strategy fits all conflicts given the complexity in which such conflicts occurs. In the light of the results this paper recommends that the effective way to address farmers-pastoralists conflicts; actors should use both lenses of coercive and participatory approaches and the choice of appropriate strategy will depends on the context since no single approach fits all types of conflicts...
\end{abstract}

Keywords: conflict, drivers, farmer, pastoralist, unethical practice

\section{Introduction}

The term conflict refers to misunderstanding, disagreement, or divergence of ideas, which result into hurting each other, and when management is delayed, it can lead into coercive measures that suggest forceful victory on either party (Norman, 2013:41). Conflicts are generally relational disputes between two or more parties, for example farmers and Pastoralist. Conflicts between farmers and pastoralists are not new phenomena. Conflicts have been reported in Holy books; for instance, in the Bible, we are told about Cain, a farmer who killed Abel who was a pastoralist (Genesis 4: 2-8; NIV, 1984). Also different scholars have reported the tension between farmers and pastoralists in different parts of the world including Africa. (Massay, 2017, Semberya, 2014, Benjaminsen et al., 2009, Areas, 2003; Abba et al., 2008). Despite conflicts becoming a common phenomenon and several efforts made to avert the situation, conflicts are reported to recur.

In Tanzania the recurrent of conflict between farmers and pastoralists is not a new phenomenon it is driven by scarcity of land resource to carter for both groups (Massay, 2017). Along the same line, other scholars have argued that the two groups for a long time have been fighting for the right to use the land which in turn results into death and loss of properties (Benjaminsen et al., 2009; Norman, 2013). Despite the fact that Tanzania is endowed with an area of 94.5 million hectares of land, out of which 44 million hectares are classified as suitable for agriculture, large proportion of land about 37.4 million hectares are protected areas such as game reserves, game controlled areas, wildlife management areas and ramsar sites (Areas, 2003; Bengesi, 2014; Bengesi et al., 2009; Semberya, 2014). These areas are specifically protected for maintenance of biological diversity, natural or associated cultural resources and managed through legal or other effective means such as protected areas. Thus, 
since this protected land is not free for use, Aarts (2012) argue that the country has been experiencing an increasing magnitude of conflict over access to land and water resources among land-users particularly between farmers and pastoralists.

The experience in Tanzania shows that recurrent conflicts between farmers and pastoralists are most noticeable during periods of drought. In such periods, pastoralists tend to move their herds to places far away from their settlements (transhumance) in search for pastures and water, and sometimes animals graze on crop farms. These recurrent conflicts between farmers and pastoralists leave hundreds of people homeless, food insecure and others dead, following burning of houses and food crops in farms (Mung'ong'o and Mwamfupe, 2003). The magnitude of the conflicts has been increasing such that state interventions have become necessary. In an effort to address the conflicts between farmers and pastoralists, the government of Tanzania was prompted to split village lands into areas for farmers and for livestock keepers. For instance, Kambala village in Mvomero District was split into two parts one for each of the major land uses -grazing and crop cultivation" (Mwamfupe, 2015).

Despite these efforts by the government, it has been reported that the conflicts have been recurring whose consequences are becoming unbearable (Mwamfupe, Ibid). This situation raises a number of questions as to why such conflicts are persistent. While literature observes that the increasing number of conflicts in various areas of farmers-pastoralists is worrisome (Areas, 2003; Semberya, 2014; Benjaminsen, et al., (2009), it is not known as to what exactly causes the recurrence of this situation. It might be possible that there are new drivers emerging or the applied strategies in addressing such conflicts are not relevant to the prevailing situation, and/or the previously identified drivers have not been dealt with accordingly. With the understanding of this situation, this paper attempts to answer the following questions; why do farmers-pastoralists conflicts recur in Kilosa and Mvomero districts? What are the new drivers of farmers-pastoralists conflicts in Kilosa and Mvemoro districts? What could be the best measures to address such conflicts in Kilosa and Mvomero districts? What are the consequences of recurrence of farmers-pastoralists conflicts in Kilosa and Mvomero districts?

In light of the above, this paper is organized into the following sections. The first section provides the theoretical review covering issues related to theories. The second section presents the methodology and the last part is on the results and discussion alongside with the conclusion and recommendations. Thus, this paper makes a useful contribution to knowledge on the existing literature and shade light on the best practical ways on how to sustainably manage conflict between farmers and pastoralists. Since such conflicts have been recurring and that are currently at an alarming situation, the finding of this paper is useful for decision and policy makers, and other stakeholders such as local government, which is responsible for among other things to ensure peace and security (Komba et al., 2018; Jesse \& Bengesi, 2018).

\section{Theoretical Review}

This paper applied two theories namely conflict theory and conflict resolution theory. The choice of these theories was based on their application in the most important aspects of social life including psychological considerations, which are important in shaping human behavior. In this view, the two theories are applied to frame the concept of drivers and consequences of recurrent conflicts.

\subsection{Conflict Theory}

According to the conflict theory, tensions and conflicts arise when resources, status, and power are unevenly distributed between groups in society, and that these conflicts become the engine for social change (Crossman, 2016. p.1). In addition, Tonah (2006) maintains that conflict theory views constant antagonism over economic resources as the fundamental cause of conflict between economic agents. The economic agents in this context are farmers and pastoralists. The point of conflict is usually when two or more parties did not reach the consensus over resources they need. Karl Marx, through conflict theory emphasizes the role of coercion and power in producing social order (Crossman, 2013). The theory upholds that social order is maintained by domination and power, rather than consensus and conformity. Those with wealth and power try to hold on to it by any means possible, chiefly by suppressing the poor and powerless. In this context, power can be understood as control of material resources and accumulated wealth, control of politics and the institutions that make up society.

However, this paper argued that it is not in all contexts that coercive power is appropriate to resolve conflicts. In other contexts, participatory approaches are much more relevant and effective. As such, this suggests that conflict theory is limited in its scope and may not support context, which requires participatory approaches since its orientation is the use of coercive power as a response to conflicts. In this view a need arises to consider conflict resolution theory, which is focused on peaceful approach of resolving conflicts. 


\subsection{Conflict Resolution Theory}

The conflict resolution theory as a discipline has developed theoretical insights into the nature and sources of conflicts and how conflicts can be resolved through peaceful methods to effectuate durable settlements. Boundless (2016) maintain conflict resolution theory believe that human behavior in social contexts results from conflicts between competing groups. The theory works along Karl Marx's contention that " $a$ society is a dynamic entity constantly undergoing changes by class conflict." The conflict perspective views social life as competition. Competition over scarce resources is at the heart of all social relationships (Boundless, 2016.p.4).

In view of the fact that conflict resolution theory considers peaceful mechanisms and more participatory approaches in addressing conflicts. This paper suggests that in situation where coercive approaches are not appropriate the conflict resolution theory is well placed to explain. Given the fact that we do not leave in an ideal environment in such a situation we expect both scenarios i.e. coercive approach and participative approach to apply when dealing with conflicts. However, there are times when you may need a combination of both approaches. It is from this context, this paper postulate that "in the real life it is not realistic to claim that one strategy fits for all types of conflicts, the possibility is that there are situations which requires coercive power and others will require participatory approaches and in some incidences you need a combination of both. In this case this paper suggests that both theories should be considered all together.

\subsection{Drivers of Conflict between Farmers and Pastoralists}

Conflicts between farmers and pastoralists have been linked to a number of drivers. Scholars identified various drivers of conflicts such as drought, land use, migration as well as traditional beliefs and practices (Mwamfupe, 2016; Benjaminsen et al., 2009; Abroulaye et al., 2015). However, the implications of these drivers on farmers and pastoralists have been detrimental in most cases. According to FAO (2005), droughts or period of unusual low rainfall is part of the expected pattern of precipitation in semi-arid Africa. Thus one of serious effect of drought is drying up of water resource and declining of forage for livestock, a situation, which results into conflicts between farmers and pastoralists (Orindi et al., 2007). Climatic variability also affects distribution and availability of these resources leading to pastoralists migrating into land occupied by farmers and hence conflicts between these two groups occur. Mancosu et al. (2015) points out that a correlation between drought and conflict already exists in Africa mainly due to increased competition for water and pasture.

Further, land conflicts often have extensive negative effects on economic, social, spatial and ecological development. This is especially true in developing countries and countries in transition economies where land market institutions are weak and opportunities for economic gain by illegal action are widespread and hence, many poor people lack access to land. Land conflicts can have disastrous effects on individuals as well as on groups and even entire nations (Adelakun, 2015; Wehrmann, 2008). Many conflicts that are perceived to be clashes between different cultures are actually conflicts over land and related natural resources. This means that everywhere people are competing for the natural resources to enhance their livelihoods.

Migration from one place to another seemed to be patterns due to chronic drought conditions. Initially, this follows pre-established labour migration patterns, and may not differ in intensity from areas with established high rates of temporary, circular migration (Judex \& Menz, 2003). In comparison to other disasters where few victims consider permanently changing location Raleigh et al.,(n.d) points out that migration is considered the highest in drought areas.

As Adeoye (2017) accentuates, pastoralists sometimes engage in deliberate destruction of crops and properties because of the belief that such acts are essential for stock growth/expansion and house prosperity. This destruction occurs through bush burning by the farmers for their various benefits, which pastoralists see as a deliberate attempt to deny livestock's access to pasture. Additionally, some pastoralists, for example, the Maasai believe that all the cattle in the world belong to them and were given to them by Enkai, (the god). Such belief has been a source of trouble with other neighboring communities by generating inter-tribal conflicts (Benjaminsen et al., 2009).

\subsection{Conceptual Framework}

Natural resources are conceived as anything (e.g. pasture, water, land, wild-fruits, etc) that originates naturally and is depended upon by social actors to derive their basic needs of food, income, shelter, and so forth, and is vulnerable to becoming scarce. The conflicts are operationalized through practices including verbal attacks (low intensity), destruction of property, injuring, and loss of life (high intensity), among others.

The previous studies emphasize that conflict occur because of interactions between and among social actors (e.g. farmers and pastoralists) that can create struggles for scarce spatially and temporally dynamic natural resources 
(Mung'ong'o and Mwamfupe, 2003; Enwelu et al., 2015). When such interactions result in adverse intolerable effects, efforts have to be undertaken by diverse stakeholders to address the resource-based conflicts and drivers thereof. In agreement with and beyond previous studies, this paper hypothesized that conflicts recur and are fueled by various drivers within and beyond the boundaries of competition for natural resources including socioeconomic, environmental factors, and unethical practice. This conceptual framework is imperative for guiding analysis and enhancing understanding on the diverse drivers for recurrence of conflicts, and its consequences. By employing this framework in operationalizing the study, this research has been enabled to come up with a thorough knowledge of holistic drivers and consequences of recurrent conflicts and has thus provided inputs in terms of policy recommendations useful for rectifying the situation.

\section{Methodology}

\subsection{The Study Area}

This study was conducted in Kilosa and Mvomero Districts of Morogoro Region, in Tanzania. Kilosa District is one of the six districts of Morogoro Region of Tanzania. Four villages were purposively selected for the study; two from each district. The selection of the villages was based on the most affected areas by natural resource use conflicts between farmers and pastoralists in Tanzania.

\subsection{Research Design, Sample Size and Sampling Procedure}

This study employed cross-sectional research design. Which involves collection of information only once from any given sample of population (Kothari, 2008). This design was used because of two main reasons. First, the information gathered from the respondents and documentary review represents the existing situation at the time of the study (Bailey, 1994) and the second reason is based on Amin's (2005) observation that design allows collection of data of given variables at a given point in time. This ensures that all the data required were collected within a short period of time, despite a relatively large sample of répondants.

The unit of analysis for this study was the households of farmers and pastoralists in Kilosa and Mvomero Districts. Using proportionate sampling 102 and 101 respondents were selected from Kilosa and Mvomero respectively to reduce uncertainty.

Table 1. Number of selected respondents per village

\begin{tabular}{|c|c|c|c|c|c|}
\hline \multirow[t]{2}{*}{ District } & \multirow[t]{2}{*}{ Village } & \multirow{2}{*}{$\begin{array}{c}\text { Total No. of } \\
\text { Population } \\
\text { (Census, 2012) }\end{array}$} & \multicolumn{2}{|c|}{$\begin{array}{c}\text { Number of selected } \\
\text { Respondents } \\
\end{array}$} & \multirow[t]{2}{*}{$\begin{array}{c}\text { Total No. of } \\
\text { Household selected }\end{array}$} \\
\hline & & & Farmers & Pastoralists & \\
\hline \multirow[t]{2}{*}{ Kilosa } & Rudewa & 18,352 & 26 & 25 & 51 \\
\hline & Msowero & 29,361 & 25 & 26 & 51 \\
\hline \multirow[t]{2}{*}{ Mvomero } & Hembeti & 21,057 & 25 & 26 & 51 \\
\hline & Mhonda & 20,354 & 25 & 25 & 50 \\
\hline Total & & & 101 & 102 & 203 \\
\hline
\end{tabular}

\subsection{Data Collection and Analysis}

Primary data was collected using both qualitative and quantitative techniques. Qualitative data collection methods comprised of interviews with 10 government officials as key informants and focus group discussions (FGDs) with farmers as well as pastoralists. Two FGD were conducted in each selected study area (district) with seven to ten respondents gathered together which helped to create a trusting atmosphere between the participants themselves and between them and the researcher as a moderator. Checklists were used to guide key informant interviews and focus group discussions. Face to face interviews were used to collect quantitative data from farmers and pastoralists, through the use of a questionnaire. This was carried out to clarify issues arising from other data collection methods. Secondary data was collected through existing documents relevant to the conflict between farmers and pastoralists obtained from various sources such as government documents including policies, guidelines, Acts and By-laws related to the conflicts between farmers and pastoralists.

Qualitative data was analyzed using content analysis whereby a combination of elements of analysis was employed to come up with information or themes. The identified themes were discussed in details with some quotations from the key informants interviews and focus group discussions. In this regard, the recorded 
components of discussion with the respondents were broken down into small units of themes to synthesize meaning, values and attitudes. On the other hand, quantitative data were analyzed using statistical package for the social sciences (SPSS) and results were presented by descriptive and inferential statistics.

\section{Results and Discussion}

This paper answers four questions; why do farmers-pastoralists conflicts recur? What are the new drivers of farmers-pastoralists conflicts? What are the consequences of recurrence of farmers-pastoralists conflicts? What could be the best measures to address such conflicts?

\subsection{Recurrence of Farmers-Pastoralists Conflicts}

This paper considers among factors accounting for recurrence conflicts between farmers and pastoralists to include socio-economic factors, unethical practices, environmental factors and regulatory framework which originated from respondents, key informants (KIs) and focus group discussion (FGDs). In the following sections, factors accounting for recurrent of conflicts between farmers and pastoralists are underscored.

\subsubsection{Socio-economic Factors}

The socio-economic characteristics of the respondents were examined in relation to conflict between farmers and pastoralists. Households' background information described in this section includes general characteristics of respondents in terms of sex, age, level of education, and main occupation. In this study, $37.4 \%$ of the respondents were between the ages of 46 and 64 years, while $29.1 \%$ were between 36 and 45 years old (Table 2). This implies that majority of respondents were at the age of active working group and responsible for decision making. According to Mwasha (2016), the age of a person usually is a factor that can explain the level of production and efficiency; it influences individual's experience, wealth and decision-making. Moreover, since the dominant age groups in this paper ranged between 46-64 and between 36-45 year old respectively, it is obvious that the groups were actively engaged in socio-economic activities of farming and pastoralists, which could easily lead to conflict due to each group struggling to fight on the same resource when satisfying their basic needs.

In terms of sex distribution, majorities (86.2\%) of the respondents were male and few (13.8\%) were females (Table 2). The presence of more male respondents was attributed to the fact that the focus of this study was on the household heads, which are conventionally men dominant in African societies. With regards to the level of education this paper assumed that the higher the level of education, the higher the ability of addressing issues confronting them (farmers and pastoralists). Based on this assumption, higher level of education was expected to address conflict in a dialogue form with an assumption that elites have higher level of analysis can avoid clashes which could results into loss of life and properties (Bengesi \& Abdalla, 2018). Given the fact that the majority (70.9\%) had low level of education this may explain why persistence of recurrent conflict was experienced.

With respect to the main occupation, there was slight difference between farmers and pastoralists. The study found that $50.7 \%$ were engaged in farming while $49.3 \%$ were pastoralists. This suggests that there was almost equal distribution of the two groups in the study area, which may imply that throughout the year there is a competition for farming and grazing over land resource between the two groups since the two groups were either solely engaged in farming or pastoralist which lead to collision. From FGDs, it was reported that occupation has renewed interests in agriculture and further encroachment to areas that were used by pastoralists for grazing and/or as stock routes. As observed directly in the study area, most areas allocated for pastoralists were much more fertile leading to farmers' encroachment in search for productive land. As a result this accelerated the occurrence of recurrent conflicts. 
Table 2. Socio-economic characteristic of respondents (farmers and pastoralists)

\begin{tabular}{|c|c|c|}
\hline \multirow[b]{2}{*}{ Socio-economic variable } & \multicolumn{2}{|c|}{ Distribution } \\
\hline & Frequency & Percent \\
\hline \multicolumn{3}{|l|}{ Sex } \\
\hline Male & 175 & 86.2 \\
\hline Female & 28 & 13.8 \\
\hline \multicolumn{3}{|l|}{ Age } \\
\hline Under 26 & 12 & 5,9 \\
\hline 26 to 35 & 41 & 20.2 \\
\hline 36 to 45 & 59 & 29.1 \\
\hline 46 to 64 & 76 & 37.4 \\
\hline Dependants $>65$ & 15 & 7.4 \\
\hline \multicolumn{3}{|l|}{ Level of education } \\
\hline No formal education & 34 & 16.7 \\
\hline Primary education & 144 & 70.9 \\
\hline Secondary education & 21 & 10.3 \\
\hline Others (College) & 4 & 2.1 \\
\hline \multicolumn{3}{|l|}{ Main Occupation } \\
\hline Farming & 103 & 50.7 \\
\hline Livestock keeping & 100 & 49.3 \\
\hline
\end{tabular}

\subsubsection{Environmental Factors}

Climate change has long been associated with droughts, occurrence of diseases, floods and the like (Lunyelele et al., 2016). Drought is considered to be one of the factors responsible for recurrence of natural resource use conflict, since it is associated with scarcity of water and pasture, which drives pastoralists to migrate to other areas where they can find water and pastures. Table 3 affirm that $59.1 \%$ of the respondents supported that drought is one of factors leading to natural resource use conflict. Similarly, literature has also shown that competition for scarce natural resources such as pasture and water aggravated by frequent droughts (Opiyo et al., 2011; Opiyo et al., 2012; Laiser, 2016). This is perceived as central to the rise of conflicts witnessed in the study area.

It is generally open that cattle need drinking water and pasture. Result in Table 3 show that majority (93.1\%) of respondents identified searching for water points and pasture as the main factors leading to recurrent of conflict between farmers and pastoralists. However, the search for water points and pastures for the pastoralists is related to lack of security on land that rural producers subsist on. One of the key informants argued:

"When the pastoralist community does not get water, they move from one place to another in search of water as they move they graze in the agricultural land and conflict erupts. If we can solve the water problem, pastoralists will have enough water and limit their movement to search water,"

Migration is common in nomadic life especially during dry seasons in search of pasture and water. Pastoralists from different parts of Tanzania such as Manyara, Shinyanga and Dodoma Regions migrate to Kilosa and Mvomero Districts to search for pastures and water for their livestock (Ringo et al., 2018a). Table 3 illustrates that $55.2 \%$ of the respondents supported that migration from one area to another is one of factors responsible for recurring conflicts between farmers and pastoralists. This is supported by Mung'ong'o and Mwamfupe (2003) that confronted with the loss of grazing land due to several geographical factors and political marginalization, some Maasai have migrated to and/or taken up other economic pre-occupations in addition to livestock keeping in different parts of Tanzania including Morogoro and Kilosa Districts. Also Officer et al., (2016) pointed that pastoralists move with their livestock searching for pastures and water and on their way they graze on farm land which results into crashes with farmers. 
Table 3. Factors accounting for recurrence of farmers-pastoralists conflicts ( $\mathrm{n}=203$ )

\begin{tabular}{lcr}
\hline Socio-economic attributes & Distribution \\
\cline { 2 - 3 } Consequences of environmental factors & Frequency & Percent (\%) \\
Search for water and pastures & & \\
Migration from one place to another & 189 & 93.1 \\
Shortage of pasture & 112 & 55.2 \\
Drought & 117 & 57.6 \\
Unethical practice & 120 & 59.1 \\
Corrupt practice & & \\
Destruction of crops and properties & 121 & 59.6 \\
\hline
\end{tabular}

\subsubsection{Over Stocking}

The increase in number of livestock is one of the factors leading to recurrent conflict between farmers and pastoralists. The occurrence of such conflicts is generally attributed to growing pressure on natural resources use, caused by large herds and the extension of cultivation. Figure 2 shows the number of cattle owned by the pastoralists in the study area; $42.6 \%$ owned herd size of cattle between 101 and 150 , while $41.8 \%$ were those with cattle between 1 and 100, those who owned 151 up to 200 cattle were $10.9 \%$ and $2.0 \%$ owned herd size of cattle above 300. From these results, it is obvious; over stocking is one of the main factors which fueled the conflict between farmers and pastoralists. These findings are in line with Ringo et al. (2018b) who reported that overstocking is common since it is a symbol of wealth and command high respect among Masai communities.

According to population statistics of livestock, the number of indigenous cattle in Morogoro region was 455,985 which is $98.9 \%$ of the total number of cattle in the region; including indigenous and improved breeds 5052 cattle equivalent to $1.1 \%$ were dairy breeds and 26 cattle equivalent to $0.006 \%$ were beef breeds. The census results show that 10,037 agricultural households in the region which is about $88 \%$ of the total agricultural households kept 0.46 million cattle. This was equivalent to an average of 46 heads of cattle per cattle-keeping-household. The district with the largest number of cattle was Ulanga which had about 213,593 cattle $(46.3 \%)$ of the total cattle in the region. This was followed by Kilosa with 77,655 cattle (16.8\%), Mvomero with 71,988 cattle (15.6\%), Kilombero with 71,511 cattle (15.5\%), Morogoro Rural with 21,601 cattle (4.7\%) and Morogoro Urban with 4,716 cattle (1.0\%). However Mvomero district had the highest cattle population density compared to other districts in the region, which had about 29 heads per $\mathrm{km}^{2}$ (URT, 2007:71). In the light of these statistics, it is evident that the number of cattle is relatively high in relation to the available land size given other land uses. It is from this context, the government launched a nationwide campaigns for the pastoralists to reduce their herd size in order to avoid conflicts with other resource users and to safeguard the environment (Mwamfupe, 2015). 


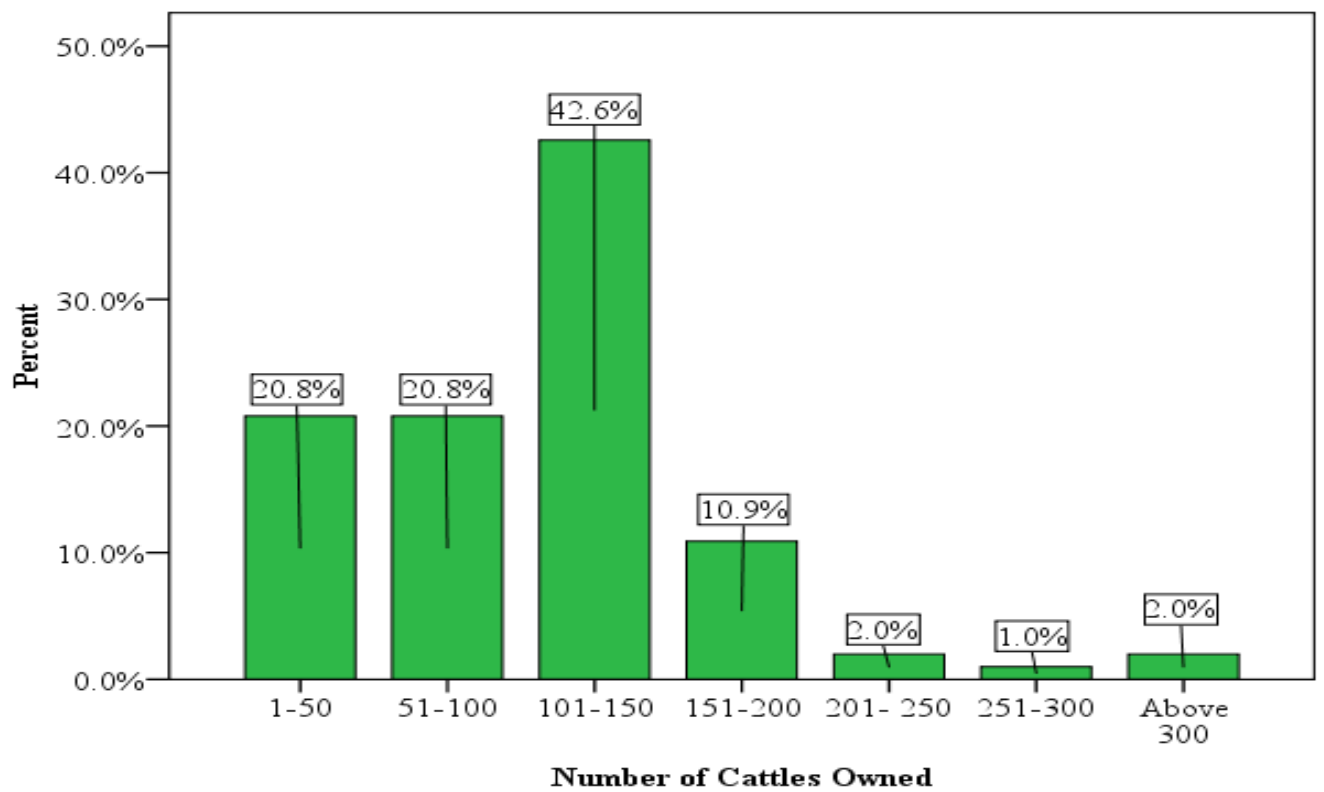

Figure 2. Increase in number of cattle

\subsubsection{Unethical Practices}

This paper revealed that unethical practices contribute to the recurring conflicts. Such practices include corrupt practices, destruction of crops and properties and hostile practice (Killing and injuring). The respondents affirmed that unethical practices fueled the natural resource use conflicts between farmers and pastoralists.

Some village leaders have been the sources of the recurrent conflicts. Table 3 shows that $59.6 \%$ of the respondents said that leaders receive bribe to allow pastoralists to enter in their villages. From the household interview, they further uncovered that the same village leaders conspired with farmers and police officers in arresting pastoralists who have trespassed in the farms. According to these respondents, these village leaders and police use pastoralist as their source of income, thus making the situation worse for pastoralists. This also creates hatred between farmers and pastoralists. It was also reported by the respondents that pastoralists bribes to obtain the permits from district officials without prior consultation with the village authorities at their destination. This practice was also reported in Svensson (2005); Blagojević (2011) where pastoralists are accused of bribing the village leaders to get permits to settle and graze their cattle in the village without consent of the village assemblies as required by the Village Land Act No. 5 of 1999.

During FGDs it was stated that "Livestock keepers being relatively richer than farmers use their economic power to win the approval of district and village leaders in their favour. As a result, clashes recur between pastoralists and farmers in such areas." In this view, weak governance structures associated with unethical behavior may explain recurrence of conflicts between farmers and pastoralists.

Also, destruction of crops and properties was reported to be a common practice in the study area. For example, $51.2 \%$ of the respondents (see. Table 3) attribute grazing on crops was among factors leading to conflicts between farmers and pastoralists. This was also supported by a key informant who described the case as follows:

One night in Kilosa District at Msowero village two friends visited my house and complained that the cattle of a pastoralist had grazed on their crops, damaging several bundles of rice they had harvested. On the following day, however, after the crop damage, the male elders met to discuss the crop damage and interviewed only the victim. The pastoralist who caused the damage was not there because he feared of farmers attack. The elders decided, after they had seen bundles of rice that had been damaged, and ordered the pastoralist to pay compensation in the form of Tshs 50000 in cash. They informed the pastoralist of their decision, giving him one week to comply. The pastoralist sold his livestock to pay for the compensation. (Source; KIs, 2014) 


\subsubsection{Policy and Regulatory Deficiencies}

The Land Policy in Tanzania (through the Land Act No 4 of 1999 and Village Land Act No. 5 of 1999) classifies land as: Reserved land; Village land; and General land. Reserved land is statutorily protected as national parks, land for public utilities, wildlife and game reserves and other land designated by sectoral legislation. Village land is the land, which is within the demarcated or agreed boundaries of any of Tanzania's villages. This land is under the managerial authority of the Village Councils, which are answerable for land management decisions to the Village Assembly (Mwamfupe, 2015:3, Bengesi et al., 2009).

General land is a residual category and includes all public land, which is not reserved land or village land and includes unoccupied or unused village land. The definition of General Land is ambiguous because unoccupied or unused village land is considered as "excess" and thus falls under the jurisdiction of the Land Commissioner rather than the village authorities. The seemingly unoccupied lands (village) may be important areas for seasonal livestock grazing, and other important livelihood uses (Mattee and Shem, 2006). Certainly, this ignores the fact that as the population grows this excess village land will actually be brought into use. However, this is actually the same land, which is, in most cases identified as suitable for agricultural investment.

Thus, the pastoralists occupying semi-arid areas are often subject to efforts to alienate their customary pastures and land holdings, for purposes of commercial investments or establishment of wildlife conservation areas (Mattee and Shem, 2006). Table 5 shows that $59.6 \%$ of the respondents affirmed that there was insecurity of land tenure which associate to land policy and $55.2 \%$ of the respondents were to support much ignoring demarcation set by them and $51.2 \%$ of the respondents affirmed that the beacons were deliberately removed. In view to this, the land policy has some deficiencies because it does not guarantee security of tenure to some users, especially smallholder groups. According to Bengesi (2014) and Bengesi et al. (2009) unsecured land tenure system in Tanzania has accounted to the underdevelopment of the land resource in the country. A secure land tenure system allows investment on land development, which could partly address most land use conflicts we observe today.

Similarly, among factors leading to the recurrent conflicts between farmers and pastoralists is the lack of security on land that rural producers subsist on (Hussein et al., 1999). Table 4 shows that $53.7 \%$ of the interviewees claimed that there was no specific area, which either the government of Tanzania or local government had set aside for grazing. In this case, pastoralists operate under constrain environment to secure adequate land for their livestock

Table 4. Regulatory framework $(\mathrm{n}=203)$

\begin{tabular}{lcc}
\hline & \multicolumn{2}{c}{ Distribution } \\
\cline { 2 - 3 } & Frequency & Percentage (\%) \\
\hline Insecurity of land tenure & 121 & 59.6 \\
Ignore to observe demarcation & 112 & 55.2 \\
Beacons removed deliberately & 104 & 51.2 \\
Lack of specific area for grazing & 109 & 53.7 \\
\hline
\end{tabular}

\subsection{Consequences of Recurrent Natural Resource use Conflicts between Farmers and Pastoralists}

It is argued that farmers and pastoralists conflicts have grown, spread and intensified over the past decade hence posing a threat to security in some countries including Tanzania (Oyama, 2014). Figure 3 demonstrates that the consequences of recurrent natural resource use conflicts between farmers and pastoralists include death, destruction of properties, destruction of crops, affected social service, hunger, migration, lack of peace, poverty, and economic deterioration. As observed by Wehrmann (2008) that the natural resource use conflicts can be considered as a disastrous agent on individuals as well as on groups and even to an entire nation, Figure 3 depicts $18.2 \%$ of respondents confirm that the consequences of conflict included loss of life for human. This finding is in line with Paaga (2013) and Benjaminsen et al. (2009) who affirmed that many conflicts in terms of clashes between the two communities resulted into the loss of people's lives.

Besides death, recurrent conflicts between farmers and pastoralists lead to physical impairment. For example, during data collection at Mkindo village inhabited by farmers, a man was found with his arm was broken due to conflict between farmers and pastoralists. In an interview he confirms; "My arm was broken during clashes between farmers and pastoralists beside been injured there was a case filed at primary court" He said that his 
arm was broken during one of the clashes between members of his village and pastoralists from the neighbouring village of Kambala inhabited by pastoralists.. Similarly, Shemdoe and Mwanyoka (2015) reported that in one of the clashes between Mkindo and Kambala villages about six people lost their lives, most of them being males. Such reported incidences have significant effect on the households, which immediately turns to be female-headed and hence increasing family-caring burden to women.

Also, frequent conflicts between farmers and pastoralists have caused destruction of properties. Figure 3 show that $20.2 \%$ of the respondents identified properties destruction as one of the effects of conflict. According to the information gathered from the respondents, $23.6 \%$ have reported that crops destruction were instigated by pastoralists cattle and have made farmers scared to cultivate their land because of crop destruction. Further, $4.9 \%$ of the respondents (see.Fig.3) said that social and extension services have been affected due to recurrent natural resource use conflict between farmers and pastoralists. The conflict has resulted into poor livestock support services such as water supplies, dips and veterinary services as well as poor provision of social services such as; schools and dispensaries located in the areas of two communities.

It is also important to note that conflicts between farmers and pastoralists have direct impact on the lives and livelihoods of those involved, Figure 3 shows that $8.3 \%$ of the respondents said that the recurrent conflicts between farmers and pastoralists has consequently resulted in poverty and hunger. This makes other people flee (6.9\%) to search for security because there is no peace (3.9\%) in the area. This argument is supported by Ukamaka et al., (2017) who argues that shocks associated with conflicts invariably impact on the livelihood of the disputants and communities at large. Abbass (2012) warned that the disharmony between farmers and pastoralists lead to constant conflict among them, and hence time to engage into productive activities is wasted.

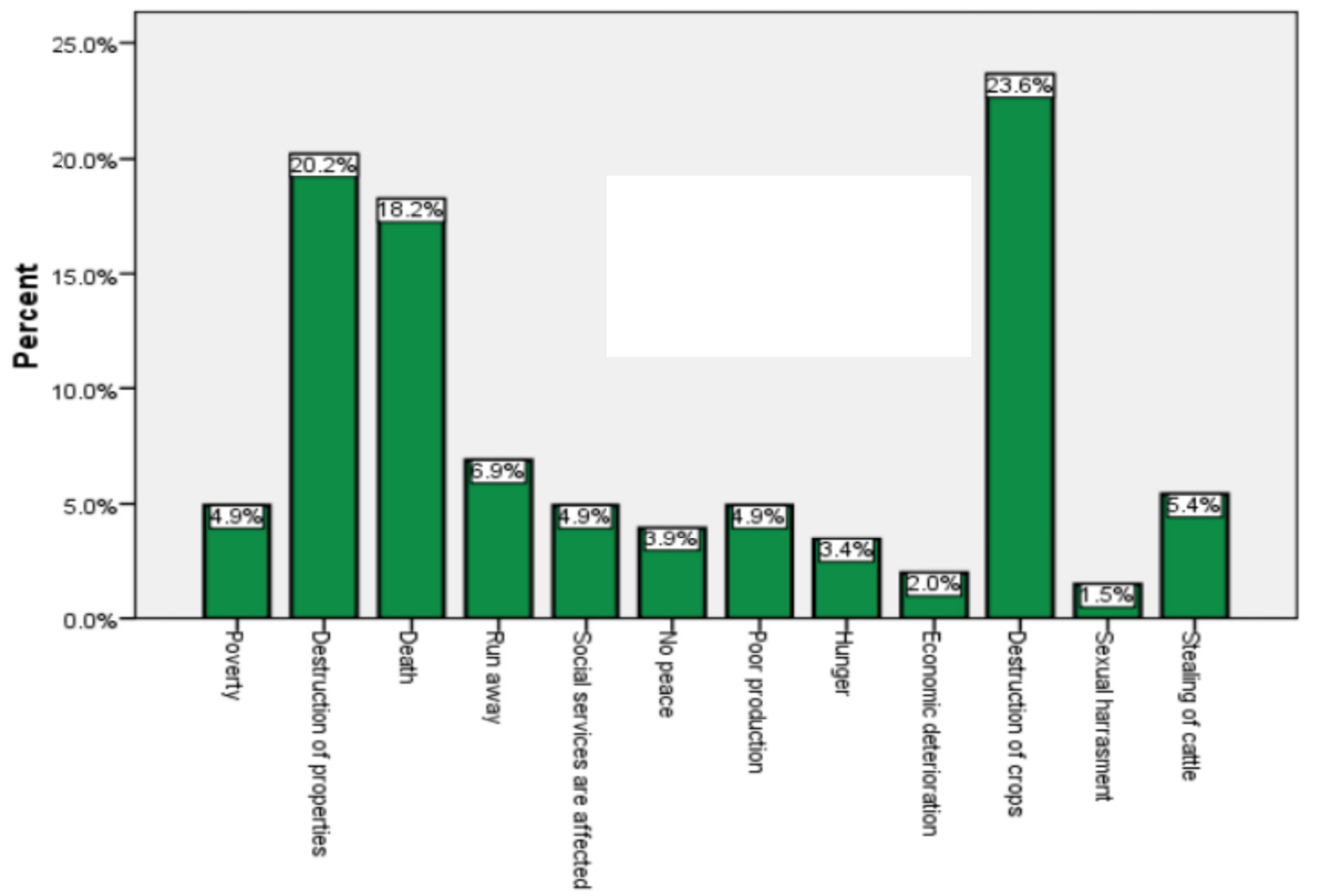

Figure 3. Consequences of conflicts of natural resource use between farmers and pastoralists

Table 5 shows that farmers $(59.1 \%)$ were often the most affected by conflict between farmers and pastoralists because farmers are sedentary as affirmed by key informants; as they were settled and have nowhere else to go. On the other hand, pastoralists (31.5\%) sometimes embark on raiding activities in communities and then disappear, making it difficult to tract them to a particular settlement. Consequently, farmers are afraid to go to their farms and no longer practice the culture of living in the farms as they formerly did, as a result weeds outgrow crops. Thus, there is a general poor harvest because crops are not properly managed by farmers. Conflict has therefore caused widespread poverty and insecurity in the farmers' community. 
Table 5. Sense of insecurity $(n=203)$

\begin{tabular}{lcc}
\hline \multirow{2}{*}{ Response } & \multicolumn{2}{c}{ Distribution } \\
\cline { 2 - 3 } & Frequency & Percent \\
\hline Farmer & 120 & 59.1 \\
Pastoralists & 64 & 31.5 \\
Both & 19 & 9.4 \\
TOTAL & $\mathbf{2 0 3}$ & $\mathbf{1 0 0 . 0}$ \\
\hline
\end{tabular}

\subsection{Contribution to Theory}

This paper has come up with potential drivers of recurrent conflicts between farmers and pastoralists in Kilosa and Mvomero Districts, which were socio-economic factors, environmental factors, unethical practices, and regulatory framework. The two theories namely conflict theory and conflict resolution theory framed this study. The conflict resolution theory emphasizes solely on solving conflict through peaceful approach to effectuate durable settlement, while conflict theory emphasizes on solving conflict by employing coercion and power dominance to restore social order. However, this paper argues that no single solution fits all conflicts; the issue of whether to use coercive force or participative approach will always depend on the context. There are contexts, which requires coercive power, others requires participative and others requires a combination of both coercive and participative. In this view, the application of these theories depends on the nature of the conflict. This may suggest that no single theory among the two i.e. conflict theory and conflict resolution theory can stand alone to explain a comprehensive solution of a conflict. In events where one need an intervention it is recommended to use lenses of both theories and chose the appropriate option that most suit the context of the conflict.

\section{Conclusions and Recommendations}

\subsection{Conclusions}

This paper explored drivers and consequences of recurrent conflicts between farmers and pastoralists. The paper observed that socio-economic factors, environmental factors, over stocking, unethical behavior, policy and regulatory deficiencies were the key drivers of recurrent conflicts between farmers and pastoralists. Therefore, the paper argued that pastoralist activities such as grazing, and search for water have a higher potential of fueling conflicts than farmers activities who are sedentary in nature. The findings show that farmers were often the most vulnerable to such conflicts for the main reason that they were in sedentary settlements. This suggests that recurrent of such conflicts is mostly driven by the lack of security of land tenure on that most smallholder producers depend for their livelihoods. Policy deficiencies and contradictions have been exploited by corrupt elite to the detriment of the poor farmers and pastoralists. Such conflicts expose local people to poverty and insecurity. Therefore, the overall impact of these will result in instability and would undermine any meaningful efforts toward archiving sustainable development in the country.

\subsection{Recommandations}

This paper shows that the recurrent conflicts are mostly due to lack of land tenure security. The paper therefore suggests that the government, policy makers and traditional group authority should develop a mechanism to ensure land security among users so that it motivates land owners to invest for land development.

Since policy deficiency and contradictions have resulted into unethical practices such as corruption, there is a need for the government to effectively establish a transparent and accountability committee where their obligation will be critically observing rules, regulations as far as land tenure is concern.

\section{Acknowledgements}

We would like to express our sincere appreciation to Sokoine University of Agriculture for giving permission to undertake this study. We are also greatly indebted for the support given during data collection by a number of stakeholders in Kilosa and Mvomero Districts, Tanzania. Special thanks should go to districts officials and all respondents in Kilosa and Mvomero Districts. 


\section{References}

Aarts, N., \& Lokhorst, A. M. (2012). The role of government in environmental land use planning: towards an integral perspective. Retrieved February 12, 2018, from https://library.wur.nl/WebQuery/wurpubs/fulltext/253292

Abba Gana Shettima and Usman A. Tar. (2008). Farmer-Pastoralist Conflict in West Africa: Exploring the Causes and Consequences. Information, Society and Justice, 1(2), 163-184.

Abbass, I. M. (2012). No Retreat, No Surrender.'Conflict for Survival between Fulani Pastoralists and Farmers in Northern Nigeria. European Scientific Journal, 8(1), 337-352.

Abroulaye, S., Issa, S., Abalo, K. E., \& Nouhoun, Z. (2015). Climate Change : A Driver of Crop Farmers - Agro Pastoralists Conflicts in Burkina Faso. International Journal of Science and Technology, 5(3), 92-104.

Adamson, N., \& King, S. (2013). Conflict Management among the Farmers and Pastoralists in Tanzania. International SAMANM Journal of Business and Social Sciences, 1(2), 40-50. Retrieved from https://www.researchgate.net/publication/311934623

Adelakun, O. E., Adurogbangba, B., \& Akinbile, L. A. (2015). Socioeconomic Effects of Farmer-Pastoralist Conflict on Agricultural Extension Service Delivery in Oyo State, Nigeria. Journal of Agricultural Extension, 19(2), 59-70. https://doi.org/10.4314/jae.v19i2.5

Adeoye, N. O. (2017). Land use conflict between farmers and herdsmen in parts of Kano, Yobe and Borno States of Nigeria: Nomads' viewpoints. Ghana Journal of Geography, 9(1), 127-151. Retrieved from https://www.ajol.info/index.php/gjg/article/download/154660/144240

Amin, A. (2005). Social Science Research, Conception, Methodology and Analysis. Kampala: Makerere University Printery.

Areas, P. (2003). Biodiversity and Protected Areas. Tanzania Biodiversity and Protected Areas - Tanzania. $\begin{array}{llll}\text { Retrieved } \quad \text { November } & 10, & \text { 2017, }\end{array}$ www.vub.ac.be/klimostoolkit/sites/default/files/documents/tanzania_bd.pdf

Bengesi, K. M. K. (2014). Assessing Impact of Biofuel Investments on Local Livelihoods in Tanzania: A case of Kisarawe, Bagamoyo and Kilwa Districts. Retrieved March 15, 2018, from http://www.mviwata.org/wp-content/uploads/2014/09/Study-Report-on-Biofuel-Investments-July2012.pdf

Bengesi, K.M.K and Abdalla, J.O. (2018). Forces Driving Purchasing Behavior of Tourists Hotels along Tourist-Agriculture Supply Chain in Zanzibar, International Journal of Marketing Studies, 10(2), 150-168. https://doi.org/10.5539/ijms.v10n2p36

Bengesi, K. M. K., Msuya, C. P., Salanga, R. J., \& Mwakalobo, A. B. S. (2009). Implication of Biofuels Production on Food Security in Tanzania. Retrieved April 13, 2013, from http://www.actionaid.org/sites/files/actionaid/implication_of_biofuels_production_on_food_security_in_tan zania.pdf

Benjaminsen, T. A., Maganga, F. P., \& Abdallah, J. M. (2009). The Kilosa killings: Political ecology of a farmer-herder conflict in Tanzania. Development and Change, 40(3), 423-445. https://doi.org/10.1111/j.1467-7660.2009.01558.x

Blagojevi, S. (2011). Impact of Private Incidence of Corruption on Performance of Firms. Retrieved January 22, 2018, from www.ef.uni-lj.si/media/document_files/events/Starebei/ICABEC_conf_2011-2.pdf

Blench, R. (1996). Aspects of resource conflict in semi-arid Africa. Natural Resource Perspectives, 16(16), 1-9. Retrieved September 17, 2017, from http://www.odi.org.uk/resources/download/2153.pdf

Boundless. (2016). The Conflict Perspective. Retrieved August 15, 2016, from https://www.boundless.com/sociology/textbooks/boundless-sociology-textbook/sociology-1/theoretical-pers pectives-in-sociology-24/the-conflict-perspective-156-974/

Crossman, A. (2016). Understanding conflict theory: A brief overview. Retrieved December 21, 2017, from https://www.thoughtco.com/conflicttheory-3026622

FAO. (2005). Global Forest Resources Assessment 2005 - progress towards sustainable forest management. FAO Forestry Paper No. 147. Rome. Retrieved November 17, 2017, from www.fao.org/docrep/008/a0400e/a0400e00.htm

Hussein, K., Sumberg, J., \& Seddon, D. (1999). Increasing Violent Conflict between Herders and Farmers in 
Africa. Claims and Evidence.Development Policy Review, 17, 97-418. https://doi.org/10.1111/1467-7679.00094

Ikejiaku, B. V. (2009). The Relationship between Poverty, Conflict and Development. Journal of Sustainable Development, 2(1), 15-28. https://doi.org/10.5539/jsd.v2n1p15

Jajere, I. A. (2015). Assessment of the Existing Natural Resource Conflict Management Institutions in the North East Arid Zone Of Nigeria. IOSR Journal Of Humanities And Social Science, 20(1), $79-85$. https://doi.org/10.9790/0837-20417985

Jesse, A. \& Bengesi, K.M.K. (2018). Planning Interface for Social Service Delivery between Local Government Authorities and Corporates in Morogoro, Tanzania. International Journal of Business, Humanities and Technologies, 8(1):68-80.

Judex, M., \& Menz, G. (2003). Modelling of land-use changes in a west african catchment, Center for Remote SensinofLandSurfaces, University of Bonn, 53113Bonn, Germany. Retrieved from www.isprs.org/proceedings/XXXVI/part7/PDF/069.pdf

Komba, A.M; Bengesi, K.M.K and Mwageni, T (2018). Planning: Concept, Theories and Models, In Lifuliro, C., Zilihona, I., Mdendemi, T., Kamanzi, A., Kinyashi, G. \& van Djik, T (eds.), Tanzania Planners' Handbook: A guide for Development Planning. African Studies Center, Leiden, Netherlands. Pp.31-41.

Kothari, C. R. (2008). Research Methodology, Methods and Techniques (2nd ed., pp. 109-110). New Delhi: New Age Inter- national (P) Limited.

Laiser, T. J. (2016). Land tenure systems and conflic ts in rural smallholder (Master Dissertation, Sokoine University of Agriculture, Morogoro, Tanzania).

Lunyelele, S.P.; Bengesi, K.M.K. \& Katani, J.Z. (2016). Awareness of Peri-urban Farmers on the Concept of Climate Change: A Case of Temeke District, Dar es Salaam Region, Journal of Environment and Earth Sciences, 6(7):24-34

Mancosu, N., Snyder, R. L., Kyriakakis, G., \& Spano, D. (2015). Water Scarcity and Future Challenges for Food Production. Water, 7(3), 975-992. https://doi.org/10.3390/w7030975

Massay, G. E. (2017). In Search of the Solution to farmer-pastoralist conflicts in Tanzania, SIIA Occasional Paper, 257 pp. 1-17. Retrieved January 9, 2018, from www.saiia.org.za/

Mattee, A. Z., \& Shem, M. (2006). Ambivalence and Contradiction: A Review of the Policy Environment in Tanzania in Relation to Pastoralism. Drylands Issue Paper No. 140. IIED, London, UK.

Msuya, D. G. (2013). Farming systems and crop-livestock land use consensus. Tanzanian perspectives. Open Journal of Ecology, 3(7), 473-481. https://doi.org/10.4236/oje.2013.37055

Muhammed, I., Ismaila, A. B., \& Bibi, U. M. (2015).An assessment of farmer-pastoralist conflict in Nigeria using GIS. International Journal of Engineering Science Invention, 4(7), 2319-6734.

Mung'ong'o, C., \& Mwamfupe, D. (2003). Poverty and changing livelihoods of migrant Maasai pastoralists in Morogoro and Kilosa districts, Tanzania.Research on Poverty Alleviation.

Mwamfupe, D. (2015). Persistence of Farmer-Herder Conflicts in Tanzania. International Journal of Scientific and Research Publications, 5(2), 1-8.

Norman, A. S. (2013). Challenges of managing elections in Africa. International Journal of Business Economics and Management Research, 3(5), 1-7.

Officer, W., Land, I., Forum, R., \& District, I. (2016). A Coalition of Farmers and Pastoralists ; An Alternative Paradigm to Resolving Land Use Conflicts. Retrieved October 5, 2017, from https://www.tnrf.org/en/content/coalition-farmers-and-pastoralists-alternative-paradigm-resolving-land-useconflicts

Opiyo, F. E. O., Mureithi, S. M., \& Ngugi, R. K. (2011). The Influence of Water Availability on Pastoralist's Resource Use in Mwingi and Kitui Districts in Kenya. Journal of Human Ecology, 35(1), 43-52. https://doi.org/10.1080/09709274.2011.11906389

Opiyo, F. E. O., Wasonga, O. V., Schilling, J., \& Mureithi, S. M. (2012). Resource-based conflicts in drought-prone North- western Kenya: The drivers and mitigation mechanisms. WUDPECKER Journal of Agricultural Research, 1(11), 442-453.

Orindi, V. A., Nyong, A., \& Herrero, M. (2007) Pastoral Livelihood Adaptation to Drought and Institutional 
Interventions in Kenya. Human Development Report 2007/2008, Fighting climate change: Human solidarity in a divided world.: United Nations Development Programme. Occasional Paper 54. New York.

Oyama, S. (2014). Farmer-Herder Conflict, Land Rehabilitation, and Conflict Prevention in the Sahel Region of West Africa. African Study Monographs, 50, 103-122.

Paaga, D. T. (2013). Customary Land Tenure and Its Implications for Land Disputes in Ghana: Cases from Wa, Wechau and Lambussie. International Journal of Humanities and Social Science, 3(18), 263-270.

Ratner, B. D., Meinzen-Dick, R., May, C., \& Haglund, E. (2013). Resource conflict, collective action, and resilience: An analytical framework. International Journal of the Commons, 7(1), 183-208. https://doi.org/10.18352/ijc.276

Ringo, J. J., Bengesi, K. M. K., \& Mbago, M. C. Y. (2018a). Access and Challenges of Health Facilities amongst Agro-pastoralist Communities in Handeni District, Tanzania. Journal of Population and Social Studies, 26(1), 153-167

Ringo, J. J., Bengesi, K. M. K., \& Mbago, M. C. Y. (2018b). Gender Determined Roles and Under-Five Mortality among Agro-pastoralist Communities in Handeni District, Tanzania. Journal of Population and Social Studies, 26(3), 218-229. https://doi.org/10.25133/JPSSv26n3.014

Security, F., Development, L., Office, P., \& Government, L. (2007). United Republic of Tanzania National Sample Census. Retrieved February 12, 2018, from https://www.google.com/search?ei=o-Q9W4yJBuSDgAapkqGQAQ\&q=United+Republic +of + Tanzania+Na tional+Sample+Census\&oq=United+Republic + of + Tanzania + National+Sample+Census\&gs_l=psy-ab.3...45 34.5749.0.6528.2.2.0.0.0.0.324.324.3-1.2.0...0...1c.1j2.64.psy-ab..0.0.0.0...318.hrkSL6gHGWU

Semberya, B. Y. D. (2014). Farmers, pastoralists conflicts: Where have we failed? Guardian Newspaper, (January). Retrieved from http://www.ippmedia.com/frontend/?1=63745

Shemdoe, R., \& Mwanyoka, I. (2015). Natural Resources Based Conflicts and Their Gender Impacts in the Selected Farming and Pastoral Communities in Tanzania, pp. 83-87. Retrieved September 9, 2017, from https://www.princeton.edu/ dixitak/home/PresAd_F1.pdf

Svensson, J. (2005). Eight Questions about Corruption. Journal of Economic Perspective, 19(3), 19-42. https://doi.org/10.1257/089533005774357860

Tonah, S. (2006). Managing farmer-herder conflicts in Ghana. Ibadan Journal of Social Sciences, 4(1), 35-45.

Ukamaka, D. M., Danjuma, S. E., Mbolle, C. J., Innocent, E., \& Mbadiwe, I. E. (2017). Livelihood issues in herdsmen- farmers' conflict among farming communities in Kogi State, Nigeria. African Journal of Agricultural Research, 12(24), 2105-2115. https://doi.org/10.5897/AJAR2017.12319

URT. (2007). United Republic of Tanzania, National Sample Census of Agriculture, Regional Report: Morogoro Regional.

Wehrmann, B. (2008). Land conflicts. A practical guide to dealing with land disputes. Deutsche Gesellschaft für Technische Zusammenarbeit (GTZ) GmbH 56726 Eschborn, Germany. pp. 122.

\section{Copyrights}

Copyright for this article is retained by the author(s), with first publication rights granted to the journal.

This is an open-access article distributed under the terms and conditions of the Creative Commons Attribution license (http://creativecommons.org/licenses/by/4.0/). 